\title{
TOWARDS VALIDATION OF A THEORY: THE RELATION OF AESTHETIC PREFERENCE AND OCCUPATIONAL GROUP MEMBERSHIP TO TIME ORIENTATION
}

\author{
A.L. THERON * \\ DEPARTMENT OF INDUSTRIAL PSYCHOLOGY \\ UNIVERSITY OF SOUTH AFRICA
}

\section{OPSOMMING}

Die verband tussen vier tydoriëntasiestyle en voorkeur vir vier groepe van non-figuratiewe skilderye en vier beroepskeuses is bepaal ten einde vas te stel of tydoriëntasie 'n geldige klassifikasiedimensie van gedrag is. Variansieontleding $(N=$ 140) toon verskille aan tussen kompleksdinamiese tydoriëntasiestyle en voorkeur vir kompleksdinamiese skilderye. 'n Gebeurlikheidsontleding dui positiewe korrelasies tussen kompleks-dinamiese tydoriëntasiestyle en geassosieerde beroepsgroepe aan en ook positiewe korrelasies tussen minder kompleksdinamiese tydoriëntasiestyle en beroepsgroepe wat konseptueel daarmee geassosieer kan word. Die resultate toon aan dat tydoriëntasie geldig mag wees vir die klassifikasie van beroepsgroepe en gedeeltelik geldig vir die klassifisering van estetiese voorkeur.

Raubenheimer (1978) postulates a classification theory in which time orientation serves as a first order classification dimension which could reflect fundamental individual and group differences. Time orientation refers to man's psychological movement on the past, present, future continuum. As a personality construct it constitutes four time orientation styles which denote individual differences with regard to experiencing and utilising time (Augustyn, 1978).

To determine whether time orientation is a valid classification dimension, its relation to aesthetic preference and occupational group membership was investigated. Aesthetic preference constituted liking for stylistically different non-figurative paintings. Structurally both paintings and time orientation involve space and movement and can therefore be linked conceptually. Occupational group membership is pertinent to the practical utility of time orientation. The time orientation styles of norm groups associated with success in particular

\footnotetext{
* Requests for reprints should be sent to the author.
} 
occupations might ultimately serve as criteria for vocational guidance and selection (Raubenheimer, 1978).

It was hypothesized that individuals differing in time orientation style would differ in aesthetic preference and in occupational group membership.

Aesthetic preference has been found to correlate with personality variables (Eysenck, 1940; 1941; Knapp \& Green, 1960; Knapp, 1964; Rosenbluh, Owens \& Pohler, 1972; Juhasz \& Paxson, 1978) as well as with occupational group membership (Knapp \& Green, 1960; Eiseman \& Coffee, Knapp \& Hofman, cited by Kavolis, 1968).

In experimental aesthetics the structural elements of art works are denoted by collative variables such as simple/complex and order/disorderly (Berlyne \& Ogilvie, 1974). Research has shown that such variables can be valid criteria in the study of art preference (Berlyne $\&$ Ogilvie, 1974; Sargent-Pollock \& Konecni, 1977; Cupchik \& Berlyne, 1979).

In this study collative variables were applied to art works as well as time orientation styles.

Four time orientation styles outlined by Augustyn (1978), namely environmentalbound, routine-bound, systematic and creative-evaluative, were conceptualised as varying on a continuum from simple and static to complex and dynamic. Augustyn (1978) found significant positive correlations between environmental-bound style, animal time (static, discontinuous) and conformity, routine-bound style, physical (clock) time, rigidity and lack of achievement motivation, systematic style, responsibility, activity and achievement motivation, and significant negative correlations between creative-evaluative style and animal and physical time.

A preference scale comprising four groups of non-figurative paintings (sub-scales) representing seven different art movements was constructed and validated. Works in each group were homogeneous in terms of the collative variables associated with the four time orientation styles (see Table 1).

\section{METHOD}

\section{Subjects}

The sample comprised four groups with a total $\mathrm{N}=140$ drawn from occupations theoretically associated by Augustyn (1978) with particular time orientation styles (see Table 2). Their maximum formal schooling varied from standard six to a D.Phil-degree. 
TABLE 1

THE RELATION BETWEEN COLLATIVE VARIABLES, TIME ORIENTATION STYLES AND ART MOVEMENTS

\begin{tabular}{|c|c|c|c|c|}
\hline \multirow{2}{*}{$\begin{array}{c}\text { Collative } \\
\text { Variables }\end{array}$} & $\begin{array}{c}\text { Simple } \\
\text { Static }\end{array}$ & $\begin{array}{c}\text { Relatively } \\
\text { Simple } \\
\text { Relatively } \\
\text { Static }\end{array}$ & $\begin{array}{c}\text { Relatively } \\
\text { Complex } \\
\text { Relatively } \\
\text { Dynamic }\end{array}$ & Complex \\
Dynamic
\end{tabular}




\section{TABLE 2}

\section{OCCUPATIONAL GROUPS AND ASSOCIATED TIME \\ ORIENTATION STYLES $(\mathrm{N}=140)$}

\begin{tabular}{|c|c|c|c|}
\hline Occupation & $\begin{array}{l}\text { Number } \\
\text { of } \\
\text { Persons }\end{array}$ & Total & $\begin{array}{c}\text { Time Orientation } \\
\text { Style }\end{array}$ \\
\hline Fireman & 15 & \multirow{3}{*}{34} & \multirow{3}{*}{ Environmental bound } \\
\hline Bus driver & 9 & & \\
\hline Diesel mechanic & 10 & & \\
\hline Administrative officer & 29 & 29 & Routine bound \\
\hline Primary school teacher & 15 & \multirow{3}{*}{37} & \multirow{3}{*}{ Systematic } \\
\hline Policeman & 17 & & \\
\hline Theology student & 5 & & \\
\hline Architect & 2 & \multirow{9}{*}{40} & \multirow{9}{*}{ Creative-evaluative } \\
\hline Economist & 6 & & \\
\hline Physician & 1 & & \\
\hline Medical technician & 1 & & \\
\hline Surveyor & 1 & & \\
\hline Personnel officer & 4 & & \\
\hline Sociologist & 2 & & \\
\hline Nurse & 13 & & \\
\hline Mathematician & 10 & & \\
\hline
\end{tabular}

The R.A. Time Orientation Questionnaire (Form B) (Augustyn, 1978), was used to classify each subject in one of the four time orientation styles. Subjects who did not show a dominant style were classified as undifferentiated.

The aesthetic preference scale was administered in the form of 32 colour-slides with eight slides in each sub-scale. The method of construction is reported elsewhere (Terblanche, 1980).

\section{Procedure}

Subjects first completed the time orientation questionnaire. After this the colour-slides were projected in random order for approximately $50 \mathrm{~m}$.secs., followed by a 20 secs. period for each item. Preference for each painting was indicated on a four-point-scale ranging between strong dislike, slight dislike, slight liking and strong liking. A score for each subject on each of the four sub-scales was obtained by summating the scores on the items of each sub-scale. 
Since both the time orientation styles and art groups were conceptualised on a continuum, further analyses were based on transformation of the ipsative time orientation questionnaire to a continuous scale. Values of one, two, three and four were allotted respectively to environmental-bound, routine-bound, systematic and creative-evaluative style responses and an individual's score was the sum of the separate scores.

\section{RESULTS}

A large percentage of the sample $(75,7)$ showed relatively complex-dynamic and complex-dynamic time orientation styles (systematic $=35$; creative-evaluative $=40,7) . A$ smaller percentage $(12,1)$ showed simple-static and relatively simple-static styles (environmental bound $=5,7$; routine-bound $=6,4$ ).

The relation between time orientation and aesthetic preference

Analysis of variance indicated that the creative-evaluative time orientation group differed significantly from the undifferentiated and routine-bound groups on the relatively complex-dynamic and complex-dynamic sub-scales respectively (see Tables 3 and 4). The other differences were not significant.

\section{$\underline{\text { TABLE } 3}$}

\section{ANALYSIS OF VARIANCE FOR TIME ORIENTATION STYLE AND RELATIVELY COMPLEX-DYNAMIC PAINTINGS}

\begin{tabular}{|l|c|c|c|c|}
\hline \multicolumn{1}{|c|}{$\begin{array}{c}\text { Time Orientation } \\
\text { Style }\end{array}$} & Average & $\begin{array}{c}\text { Standard } \\
\text { Deviation }\end{array}$ & F-value & $\mathrm{p}$ \\
\hline Environmental-bound & 16,88 & 6,29 & & \\
Routine-bound & 12,78 & 7,26 & & \\
Systematic & 15,84 & 7,63 & 3,47 & 0,01 \\
Creative-evaluative & 18,70 & 6,21 & & \\
Undifferentiated & 12,59 & 7,91 & & \\
\hline
\end{tabular}


$\underline{\text { TABLE } 4}$

\section{ANALYSIS OF VARIANCE FOR TIME ORIENTATION STYLE AND COMPLEX-DYNAMIC PAINTINGS}

\begin{tabular}{|l|c|c|c|c|}
\hline \multicolumn{1}{|c|}{$\begin{array}{c}\text { Time Orientation } \\
\text { Style }\end{array}$} & Average & $\begin{array}{c}\text { Standard } \\
\text { Deviation }\end{array}$ & F-value & $\mathrm{p}$ \\
\hline Environmental-bound & 17,63 & 7,17 & & \\
Routine-bound & 14,33 & 4,64 & & \\
Systematic & 17,27 & 6,09 & 5,44 & 0,00 \\
Creative-evaluative & 21,46 & 5,83 & & \\
Undifferentiated & 16,59 & 6,55 & & \\
\hline
\end{tabular}

By viewing the time orientation questionnaire as a continuous scale, significant correlations between time orientation style and all four sub-scales were indicated (see Table $5)$.

\section{TABLE 5}

\section{CORRELATION COEFFICIENTS FOR TIME ORIENTATION STYLE AND AESTHETIC SUB-SCALES}

\begin{tabular}{|l|c|c|}
\hline Aesthetic Sub-scales & $\mathrm{r}$ & $\mathrm{p}$ \\
\hline Environmental-bound & 0,21 & 0,00 \\
Routine-bound & 0,23 & 0,00 \\
Systematic & 0,30 & 0,00 \\
Creative-evaluative & 0,32 & 0,00 \\
\hline
\end{tabular}

The findings suggest a relation between complex-dynamic time orientation style and preference for the paintings with similar structural properties as well as overall preference for all four groups of non-figurative paintings. Both findings suggest that individuals differing in time orientation differ in aesthetic preference. On the whole, the hypothesis was however not confirmed.

The relation between time orientation style and occupational group membership

A contingency-coefficient indicated significant relations between three of the four occupational groups and time orientation style. The majority of the group theoretically associated with routine-bound style showed systematic style, whilst the group associated with systematic style classified accordingly and in creative-evaluative style, which also included the majority of the group associated with creative-evaluative style (see Table 6). 
The results substantiate the hypothesis that individuals differing in time orientation style differ in occupational group membership.

\section{DISCUSSION}

The analyses mainly yielded results for the relatively complex-dynamic and complexdynamic constituents of the variables. Since the majority of the sample were classified in relatively complex-dynamic and complex-dynamic time orientation styles, the relations indicated provided fair evidence that time orientation is a valid classification dimension. The correlation between occupational group membership and time orientation style verified findings by Augustyn (1978).

\section{$\underline{\text { TABLE } 6}$}

\section{CONTINGENCY TABLE FOR OCCUPATIONAL GROUP AND TIME ORIENTATION STYLE}

\begin{tabular}{|c|c|c|c|c|c|c|}
\hline \multirow{2}{*}{$\begin{array}{l}\text { Occupational } \\
\text { group }\end{array}$} & \multicolumn{5}{|c|}{ Time Orientation } & \multirow[b]{2}{*}{ Total } \\
\hline & $\begin{array}{l}\text { Environmental- } \\
\text { bound }\end{array}$ & $\begin{array}{l}\text { Routine- } \\
\text { bound }\end{array}$ & Systematic & $\begin{array}{l}\text { Creative- } \\
\text { Evaluative }\end{array}$ & $\begin{array}{l}\text { Undiffe- } \\
\text { rentiated }\end{array}$ & \\
\hline \multirow{2}{*}{$\begin{array}{l}\text { Environmental- } \\
\text { bound }\end{array}$} & 1 & 4 & 11 & 9 & 9 & 34 \\
\hline & 2,9 & 11,8 & 32,4 & 26,5 & 26,5 & 24,3 \\
\hline \multirow{2}{*}{ Routine-bound } & 3 & 1 & 18 & 5 & 2 & 29 \\
\hline & 10,3 & 3,4 & 62,1 & 17,2 & 6,9 & 20,7 \\
\hline \multirow{2}{*}{ Systematic } & 2 & 3 & 15 & 14 & 3 & 37 \\
\hline & 5,4 & 8,1 & 40,5 & 37,8 & 8,1 & 26,4 \\
\hline \multirow{2}{*}{$\begin{array}{l}\text { Creative- } \\
\text { evaluative }\end{array}$} & 2 & 1 & 5 & 29 & 3 & 40 \\
\hline & 5,0 & 2,5 & 12,5 & 72,5 & 7,5 & 28,6 \\
\hline \multirow{2}{*}{ Total } & 8 & 9 & 49 & 57 & 17 & 140 \\
\hline & 5,7 & 6,4 & 35,0 & 40,7 & 12,1 & 100,0 \\
\hline
\end{tabular}

Chi-square $=40,098$

$$
\mathrm{p}=0,00
$$

Contingency-coefficient $=0,472$

The study was explorative, therefore the hypotheses were stated generally and the intergroup differences interpreted accordingly. Of theoretical importance, however, is "...the presence of a difference in a certain direction..." (Meehl, 1967, 105). The nature of the measurement instruments facilitated interpretation of differences in certain directions.

Correspondence between creative-evaluative time-orientation style and both aesthetic preference and occupational group membership was in the direction expected. The 
occupational group theoretically associated with systematic time orientation style classified accordingly and in the adjacent complex dynamic part of the time continuum. The implications of the findings could, if verified, contribute to the predictive value and content of the theory. In theory-building ad hoc hypotheses low in content and high in probability contribute minimally to the quality of a theory. Hesse (1974) indicates that a theory is strong in content if it covers a wide spectrum of facts and is specific in its description of each.

A requirement for effective theory-building is falsifiability (revision potential). Certain results suggest revision potential of the concepts "environmental-bound" and "routine-bound" time orientation styles as measured by the R.A. Time Orientation Questionnaire. The small percentage of subjects classified in these styles and the unexpected classification of the occupational group theoretically associated with routine-bound style as systematic, could be investigated by further research on the content of the construct time orientation and expected relations with other variables.

Validation of the aesthetic preference scale (Terblanche, 1980) indicated correlations between higher qualifications (post-school) and the four sub-scales ( $p=0,00$ for each scale). Of the total sample all the subjects with higher qualifications (except policemen) constituted the theoretically relatively complex-dynamic and complex-dynamic parts of the time continuum (see Table 2). Differences between the complex-dynamic time group and other groups in preference for the corresponding and adjacent art group (see Tables 3 and 4) as well as the art as a whole, could be related to the correlations between higher qualifications and the aesthetic scale. Appreciation of non-figurative art requires a certain degree of sophistication or education from the viewer. The content of the measurement instrument could thus have been an intervening variable which confounded the results regarding time orientation and aesthetic preference.

Collative variables, borrowed from experimental aesthetics, were theoretically linked to the construct time orientation. Walker (1973) maintains that preference and complexity are potentially criteria for explaining any form of behaviour. Empirical outline of the construct time orientation in terms of collative variables might yield a supplementary basis for utilising the construct as a classification dimension.

Due to the small sample incorporated in this study, conclusions and recommendations should be viewed with caution. 
Augustyn, J.C.D. Tyd as 'n fundamentele konsep in menslike gedrag met spesifieke verwysing na die beroeps- en bedryfswêreld. Unpublished doctoral dissertation, University of Stellenbosch, 1978.

Berlyne, D.E. \& Ogilvie, J.D. Dimensions of perception of paintings. In Berlyne, D.E. (Ed.) Studies in the new experimental aesthetics: Steps toward an objective psychology of aesthetic appreciation. Washington, D.C.: Hemisphere, 1974.

Cupchik, G.C. \& Berlyne, D.E. The perception of collative properties in visual stimuli. Scandinavian Journal of Psychology, 1979, 20, 93-104.

Eysenck, H.J. The general factor in aesthetic judgements. British Journal of Psychology, 1940, 31, 94-102.

Eysenck, H.J. "Type"-factors in aesthetic judgements. British Journal of Psychology, 1941, 31, 262-270.

Hesse, M. The structure of scientific inference. London: Macmillan, 1974.

Juhasz, J .B. \& Paxson, L. Personality and preference for painting style. Perceptual and Motor Skills, 1978, 46, 347-349.

Kavolis, V. Artistic expression: A sociological analysis. Ithaca, New York: Cornell University Press, 1968.

Knapp, R.H. An experimental study of a triadic hypothesis concerning the sources of aesthetic imagery. Journal of Projective Techniques and Personality Assessment, 1964, 28, 4954.

Knapp, R.H. \& Green, S.M. Preferences for styles of abstract art and their personality correlates. Journal of Projective Techniques and personality Assessment, 1960, 24 , 396-402.

Meehl, P.E. Theory-testing in psychology and physics: A methodological paradox. Philosophy of Science, 1967, 34, 103-115.

Raubenheimer, I.v.W. Raamwerk vir die ontwikkeling van 'n 4-dimensionele teorie van menslike gedrag. Perspectives in Industrial Psychology, 1978, 4(5), 33-72.

Rosenbluh, E.S., Owens, G.B. \& Pohler, M.J. Art preference and personality. British Journal of Psychology, 1972, 63(3), 441-443.

Sargent-Pollock, D.N. \& Konecni, V.J. Evaluative and skin-conductance responses to Renaissance and twentieth-century paintings. Behavior Research Methods and Instrumentation, 1977, 9(3), 291-296.

Terblanche, A.L. Die verband tussen tydoriëntasie en estetiese voorkeur in enkele beroepsgroepe. Unpublished masters, thesis, Rand Afrikaans University, 1980.

Walker, E.L. Psychological complexity and preference: a hedgehog theory of behaviour. In D.E. Berlyne and K.B. Madsen (Reds). Pleasure, Reward, Preference: Their Nature, Determinants and Role in Behavior. New York: Academic Press, 1973. 